\title{
Effect of Green Tea on Development of Atherosclerogenic Lesions Induced by Experimentally Hydrogen Peroxide in Female Rat Experimental ${ }^{\star}$
}

Al-Kennany ER

Dept. of Pathology / Veterinary Medicine
Al-Khafaf AA Dept. of Biology / Education for Girls

\section{الخلاصة}

تضنتت هذه الدراسة معرفة قابلية الشابي الاخضر كمضاد للاكسدة و التعصد في انساث

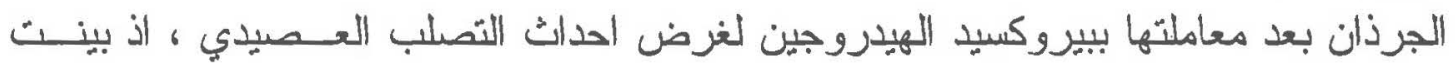

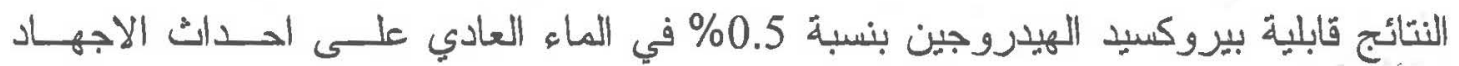

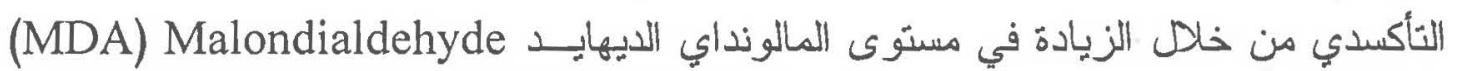

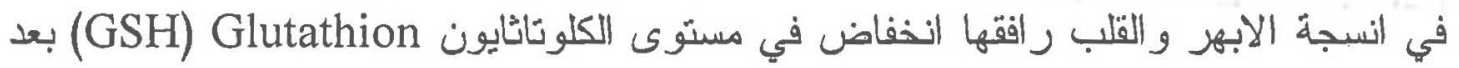
مرور 60 يوما من المعاملة . كما واظهرت النتائج قابلية الشاي الاخضر في خفض معدل كل من MDA انسجة الابهر و القلب ورفع مستوى GSH فضلا عن رفع مستوى الدهون العالية الكثافة (High density lipoprotein (HDL-c) وخفض مستوى الدهون الو اطنئة الكثافـــة - بعد قياسها في مصل الام Low density lipoprotein (LDL-c)

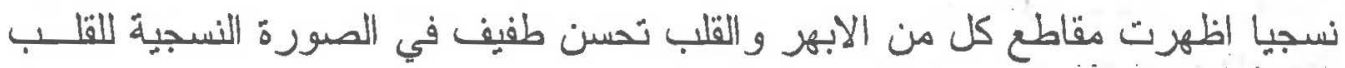

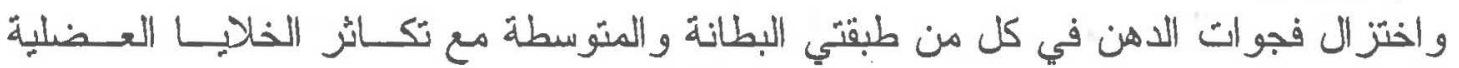

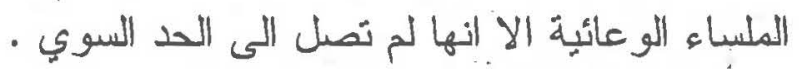

\section{ABSTRACT}

This study was conducted to investigate the ability of green tea as antioxidant and antiatherogenic in female rats after treated with $0.5 \%$ of $\mathrm{H}_{2} \mathrm{O}_{2}$ in order to induced atherosclerosis. The results showed capability of $\mathrm{H}_{2} \mathrm{O}_{2} \quad 0.5 \%$ to initiate of oxidative stress via significant increase in tissue MDA in aorta and heart associated with decrease in GSH, as well as, increase in HDL-c and decrease in LDL-c in serum of treated rats.

Histologically, aorta and heart sections revealed less improvement in histological picture, reduction lipid vacuoles in both intimal and medial

- Presented at the first conference on Biology, University of Mosul, college of Education, 4-5 September 2007 
layers associated with proliferation of vascular smooth muscle cells but it not reach to normal tissue.

\section{Introduction}

Green tea is rich in antioxidants, biologically have many active polyphenolic flavonoid commonly known as catechins, which make up $30 \%$ of the dry weight of it's leaves (1). This catechins is a well characterized, antioxidant, antitumorigenic, anti-inflammatory and antiatherogenic properties $(2,3)$.

Some studies illustrate the tea consumption particularly green trended to reduce the development of aortic atherosclerosis in rabbits (4). So, tea has recently received attention as a proposed for dietary intervention in cardiovascular diseases $(5,6)$, because oxidative stress has been implicated in vascular injury and atherogenesis (3).

In this study we used $\mathrm{H}_{2} \mathrm{O}_{2}$ in $0.5 \%$ (7) to induce oxidative atherogenesis in wall of aorta experimentally to answer the question: whether green tea treatment modulates early stage of atherosclerosis?, also to examine the role of green tea on proliferation and development of this lesions.

\section{Materials and Methods}

Female albino rats (20) weighting between 300-350mg of 3-4 months age were used. The animals were reared in wire cages feed standard diet and given tap water ad Libitum, and housed in a constant $\left(22-25^{\circ} \mathrm{C}\right)$ temperature environment with $12 \mathrm{~h}$. light and $12 \mathrm{~h}$. dark cycle. Animals were divided into four group of five rats each. Group 1 received regular rat diet and maintained as a control group; group II rats subjected to experimentally induced oxidative stress by the ad Libitum supply of drinking water containing $0.5 \% \quad \mathrm{H}_{2} \mathrm{O}_{2}$ (V/V) [Degussa $\mathrm{AG}$ merl Rheinfelden, Belgium] was prepared daily over entire 60 days period of the experiment ( 60 days), after the end of 60 days of $\mathrm{H}_{2} \mathrm{O}_{2}$ treated five animals were selected randomly to serve as the green tea (camellia sinesis) treated group (group III), animal of this group received Green tea extract for 40 days, which prepared according to (8). Group IV received only the regular rat diet and subjected Green tea of drinking ( 2 cups) was prepared daily.

At the end of the experiment period, rats were bled, and plasma samples were analysed after collection of blood samples after an overnight fast for 12-14h. and analysis performed in fresh heparin-treated plasma. The lipid parameter Tch, TGs, LDL-c, vLDL-c were determined by using a standard enzymatic assay (Bio Mericuk-Marcy-I'Eroile France), wherase LDL-c was calculated by the Friedewald formula:

$\mathrm{LDL}-\mathrm{c}=\mathrm{HDL}-\mathrm{c}-\mathrm{TGs} / 5$ 

MDA by thiobarbituric acid (TBA) test as previously described by Gilbbert et al. (9). GSH concentration of aorta and heart was measured according to Moron et al. (10).

For histopathological study, rats killed by anesthesia, aorta were dissected from the arch to the bifurcation, rinsed with isotonic saline and opened along the intercostal. The opened aortas were flattened on strips of paper with the intimal side up, after adherence to the paper strips, the vessels were fixed face down over night with $10 \%$ buffered formalin at room temperature.

Fixed aortas were stained with sudan IV as previously described Drury and Willington (11) to visualize areas of atherosclerotic plague.

After fixation of aorta and heart, tissue blocks were routinely

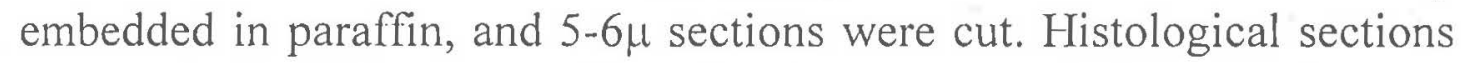
were stained with haematoxylin and eosin ( $\mathrm{H}$ and $\mathrm{E}$ ) (11).

Statistical analysis: Differences among control and treated group were tested using ANOVA followed by Tukey's test. Differences of $\mathrm{P}<0.05$ were considered significant.

\section{Chemical assay:}

\section{Results}

Table -1 showed that $0.5 \%$ of $\mathrm{H}_{2} \mathrm{O}_{2}$ in drinking water significantly increase in total cholesterol (Tch) triglycerides (TGs), low density lipoprotein (LDLc), very low density lipoprotein (vLDLc) and athergenic index, while high density lipoprotein (HDLc) showed decreased significantly compared with untreated control female rats.

In female rats subjected to $\mathrm{H}_{2} \mathrm{O}_{2}$ and green tea, the lipid profiles indicated decrease of Tch, TGs, LDL-c, vLDL-c. in these rats the level of LDL-c increase significantly $(58.60 \pm 0.06)$. (Table-1) with green tea, the picture of lipid profiles illustrated an increase of TGs $(63.21 \pm 0.52)$ and HDL-c (65.52 \pm 2.1$)$ with concomitant decrease in Tch, LDL-c as compared with control value (Table-1).

\section{Tissue MDA concentration:}

Tissue (aorta and heart) TBA reactive substance were significantly increase in female rats after 60 days of $\mathrm{H}_{2} \mathrm{O}_{2}$ treatment as compared with control group (Table-2). The greatest decrease in MDA content was seen in aorta and heart in rat treated with green tea only and $\mathrm{H}_{2} \mathrm{O}_{2}$ with green tea. Green tea supplementation in drinking water resulted a significant reduction of lipid peroxidation product, induced by $\mathrm{H}_{2} \mathrm{O}_{2}$ normalized the MDA value.

\section{Tissue GSH content:}

Table-2 showed tissue (aorta and heart) GSH content after 60 days of $\mathrm{H}_{2} \mathrm{O}_{2}$ treatment, they were significant reduction as compared with 
control value. Green tea supplementation kept the aortic GSH within the normal value. It induced a significant decrease in aorta and heart GSH in rat treated with $\mathrm{H}_{2} \mathrm{O}_{2} 0.5 \%$.

\section{Macroscopic lesions:}

Fatty streak of intimal aorta was seen in rats treated with $\mathrm{H}_{2} \mathrm{O}_{2}$ after 60 days. This fatty streaks were detected only after gross sudan staining and showed reduction in fatty streak in three of 5 rats in aortic intima and media.

\section{Microscopic lesions:}

Aorta: aortic lesions were seen in rats treated with $\mathrm{H}_{2} \mathrm{O}_{2}$ for 60 days characterized by presence of fatty streak, intimal thickening due to presence of lipid vacuole, foam cells, collagen, elastin destruction and spindle-shaped cells and degeneration of vascular smooth muscle cells (VSMc). (Fig. 1, 2).

In control and green tea treated, rats aortae revealed no pathological changes (Fig. 3), while in treated with $\mathrm{H}_{2} \mathrm{O}_{2}$ and green tea, showed proliferation of VSMc in media toward the intima, degeneration of some VSMc. Small lipid vacuole and numerous foam cells and proliferation in fibroblast cells (Fig. 4, 5).

Heart: There were no pathological lesion in rats of control group. Heart of groups. $\mathrm{H}_{2} \mathrm{O}_{2}$ and $\mathrm{H}_{2} \mathrm{O}_{2}$ with green tea revealed fatty change, congestion in coronary arteries, infiltration of mononuclear inflammatory cells (lymphocytes) and edema between muscle bundles (Fig. 6, 7). 
Table 1: Level of lipid profile in serum of female rat treated with green tea and $0.5 \% \mathrm{H}_{2} \mathrm{O}_{2}$ with green tea.

\begin{tabular}{||c|c|c|c|c|c|c||}
\hline Groups & $\begin{array}{c}\text { Tch } \\
\mathrm{mg} / \mathrm{ml}\end{array}$ & $\begin{array}{c}\text { TGs } \\
\mathrm{mg} / \mathrm{ml}\end{array}$ & $\begin{array}{c}\text { HDL-c } \\
\mathrm{mg} / \mathrm{ml}\end{array}$ & $\begin{array}{c}\text { LDL-c } \\
\mathrm{mg} / \mathrm{ml}\end{array}$ & $\begin{array}{c}\text { vLDL-c } \\
\mathrm{mg} / \mathrm{ml}\end{array}$ & $\begin{array}{c}\text { atherogenic } \\
\text { index }\end{array}$ \\
\hline Control & $95.24 \pm 0.51$ & $61.21 \pm 0.31$ & $63.55 \pm 0.21$ & $12.64 \pm 0.21$ & $19.04 \pm 0.31$ & $1.4 \pm 0.21$ \\
\hline $\mathrm{H}_{2} \mathrm{O}_{2}$ & $197.88 \pm 2.51$ & $90.83 \pm 0.24$ & $50.61 \pm 0.51$ & $129.01 \pm 0.21$ & $181.10 \pm 0.21$ & $3.90 \pm 0.2$ \\
\hline $\begin{array}{c}\text { Green tea } \\
\mathrm{H}_{2} \mathrm{O}_{2}+\text { Green } \\
\text { tea }\end{array}$ & $91.31 \pm 0.41$ & $63.21 \pm 0.52$ & $65.52 \pm 2.1$ & $19.94 \pm 0.33$ & $11.84 \pm 2.1$ & $0.9 \pm 0.22$ \\
\hline
\end{tabular}

- Values are expressed as means \pm S.D. of 5 rats per group.

- Means with same superscript in the same column are not significantly different from others $(\mathrm{P}<0.05)$.

Table 2: Level of MDA and GSH in aorta and heart of female rats treated with $\mathrm{H}_{2} \mathrm{O}_{2}$, green tea and $\mathrm{H}_{2} \mathrm{O}_{2}$ with green tea comparison with control.

\begin{tabular}{||c|c|c|c|c||}
\hline \multirow{2}{*}{ Groups } & \multicolumn{2}{|c|}{ MDA } & \multicolumn{2}{c||}{ GSH } \\
\cline { 2 - 5 } & Aorta & Heart & Aorta & heart \\
\hline Control & $440.91 \pm 9.23$ & $501.52 \pm 19.17$ & $2.31 \pm 0.12$ & $1.21 \pm 0.03$ \\
\hline $\mathrm{H}_{2} \mathrm{O}_{2}$ & $680.11 \pm 11.7$ & $689.51 \pm 12.71$ & $1.06 \pm 0.12$ & $1.01 \pm 0.13$ \\
\hline Green tea & $212.04 \pm 9.02$ & $550.12 \pm 17.78$ & $2.78 \pm 2.12$ & $1.86 \pm 1.12$ \\
\hline $\mathrm{H}_{2} \mathrm{O}_{2}+$ Green tea & $601.21 \pm 12.12$ & $650.52 \pm 12.07$ & $1.99 \pm 0.56$ & $1.12 \pm 0.32$ \\
\hline
\end{tabular}

- Values are expressed as means \pm S.D. of 5 rats per group.

- Means with same superscript in the same column are not significantly different from others $(\mathrm{P}<0.05)$. 


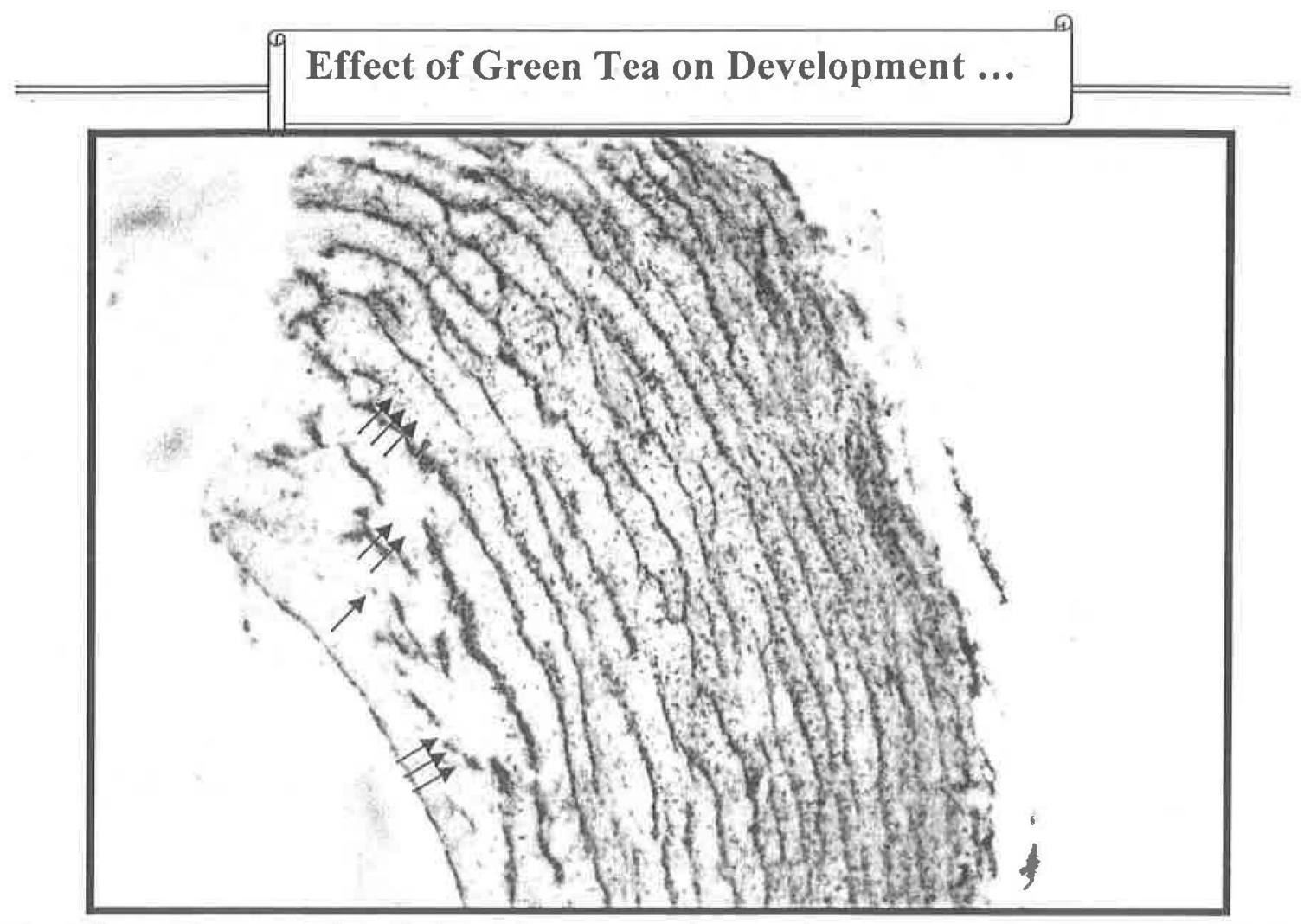

Fig.1: Histomicrograph of female rat aortic sections treated with $0.5 \% \mathrm{H}_{2} \mathrm{O}_{2}$ after 60 days, revealed thickening in initima and media $(\longrightarrow)$ due to deposition of lipid vacuoles $(\longrightarrow)$ destruction in elastic and collagen fibers $(\vec{\longrightarrow})$ H \& E. $200 x$.

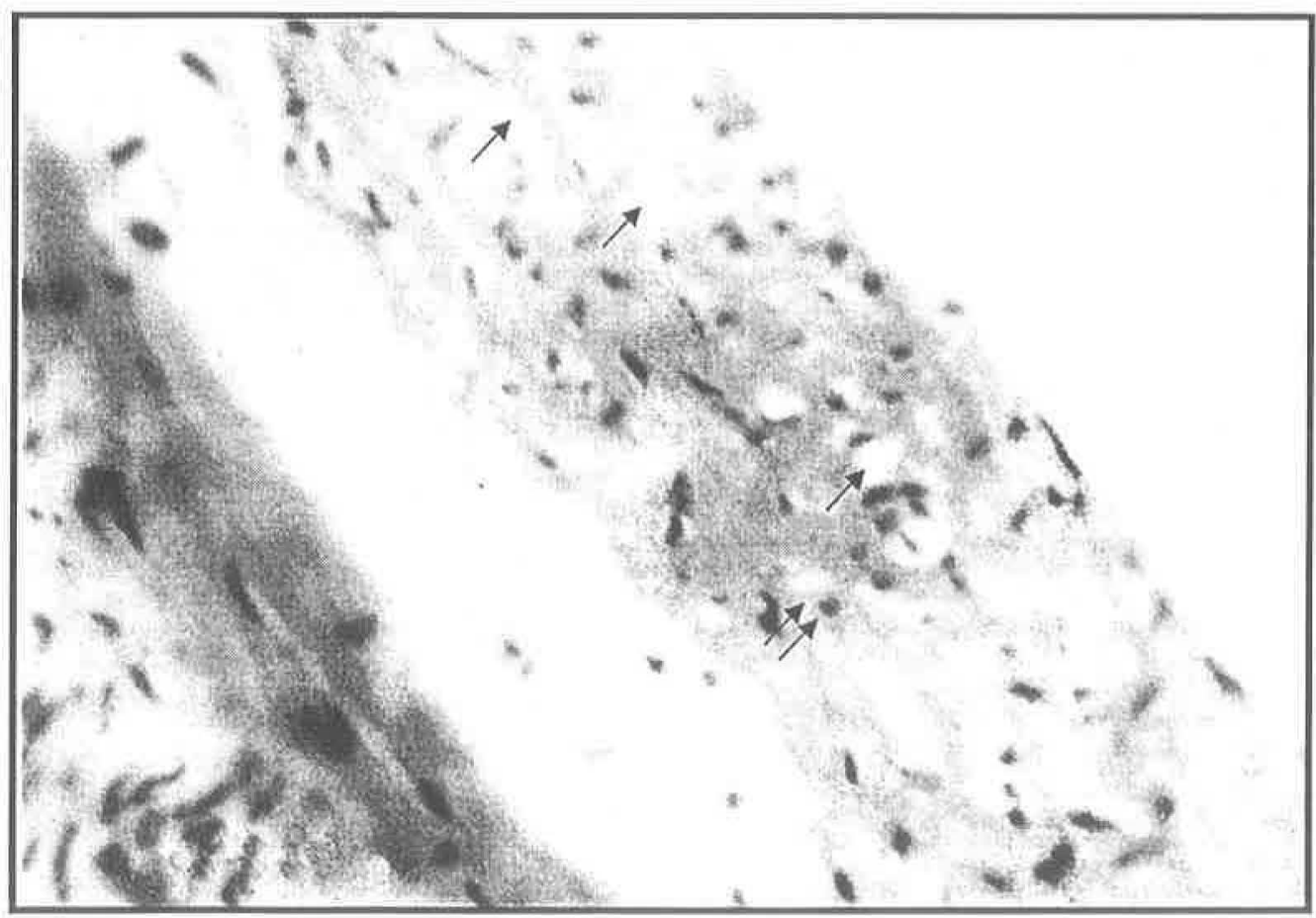

Fig.2: Histomicrograph of female rat aortic sections treated with $0.59 \% \mathrm{H}_{2} \mathrm{O}_{2}$ after 60 days, revealed deposition of lipid vacuole and Foam cells in intima and media layers $(\longrightarrow$ ) degeneration of VSMcs ( $\longrightarrow$ ). H \& E. 400x. 


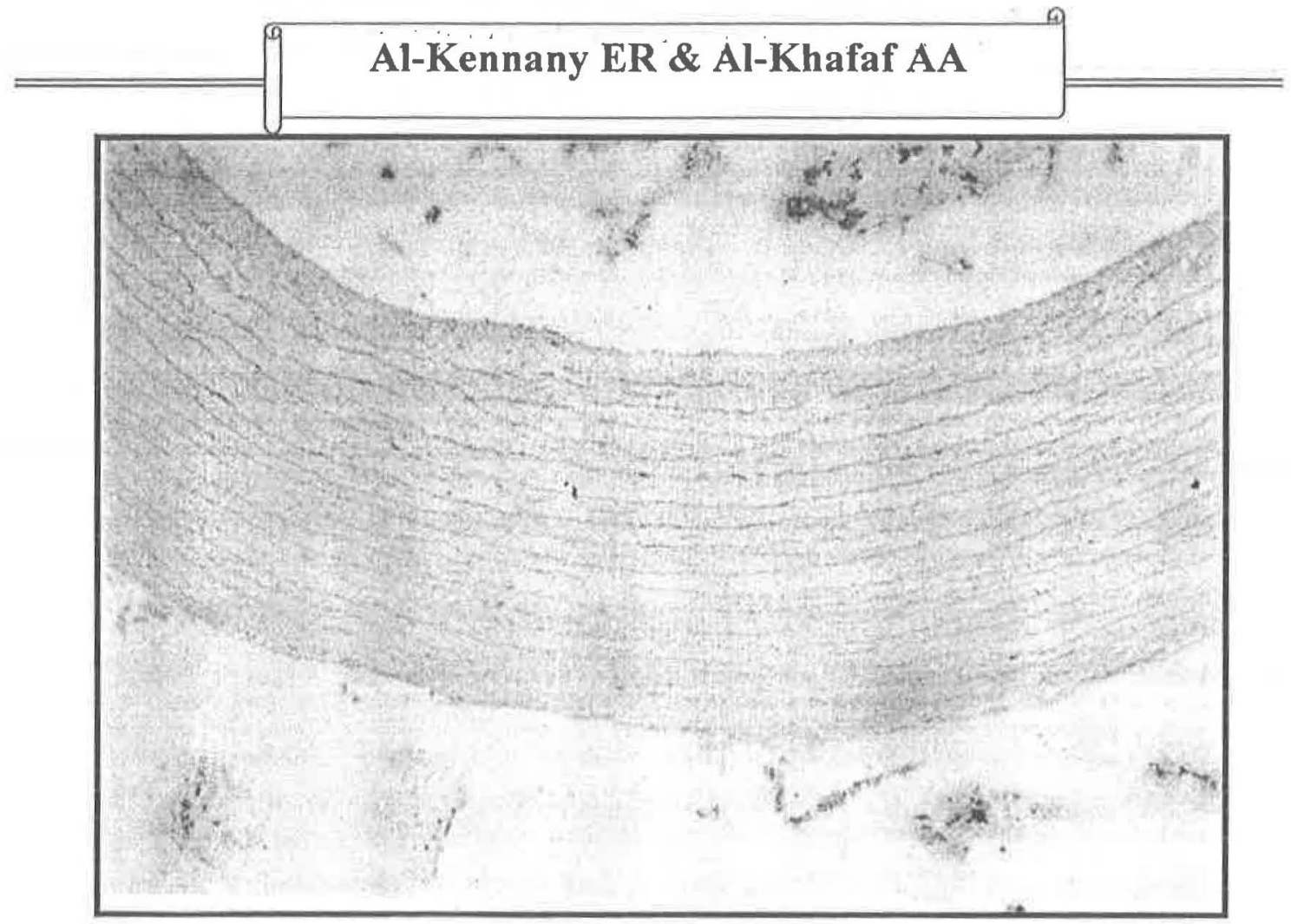

Fig.3: Histomicrograph of female rat aortic sections treated with green tea, revealed no pathological lesions in intima and media. H \& E. 100x.

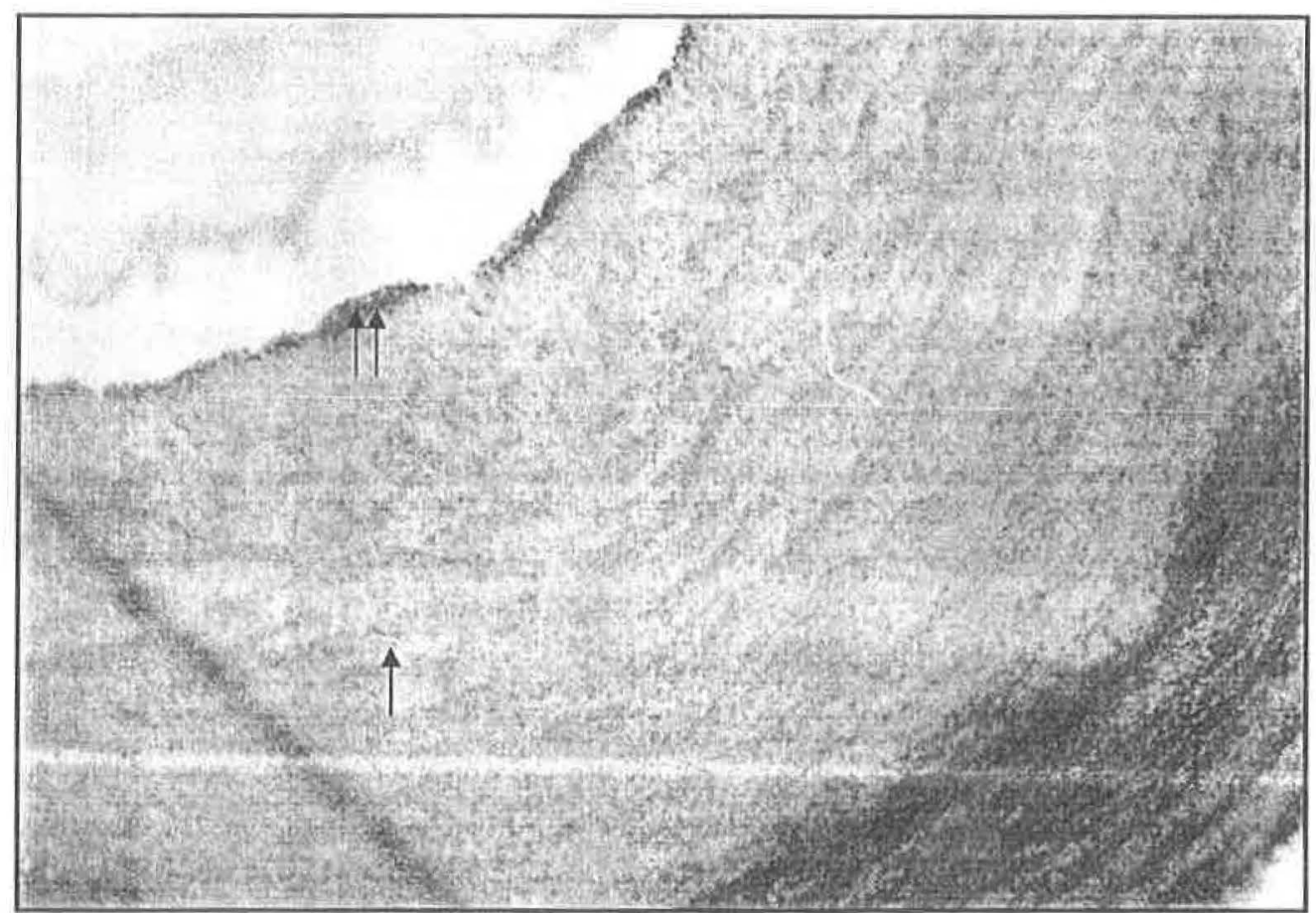

Fig.4: Histomicrograph of female rat aortic sections treated with $0.5 \% \mathrm{H}_{2} \mathrm{O}_{2}$ for 60 days then treated with green tea for 40 days, revealed proliferation lesions $(\rightarrow)$, in VSMcs and hypertrophy of endothelial cells $(\rightrightarrows)$. H \& E. 200x. 


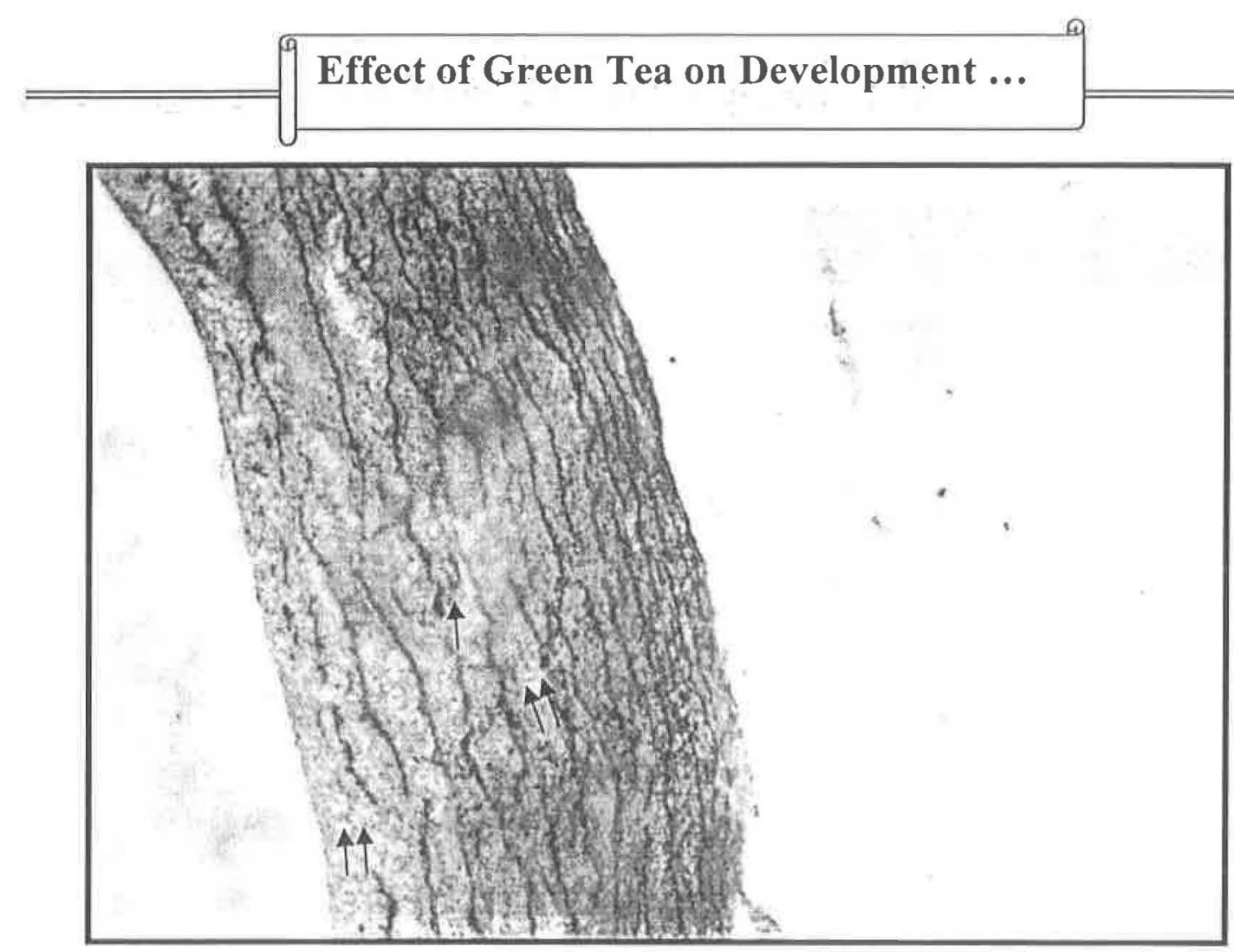

Fig.5: Histomicrograph of female rate aortic sections treated with $0.5 \% \mathrm{H}_{2} \mathrm{O}_{2}$ for 60 days them treated with green tea for 40 days, revealed proliferation in VSMcs ( $\longrightarrow$ ), deposition of lipid vacuoles in intima and media $(\Longrightarrow)$. H\& E. $200 \mathrm{x}$

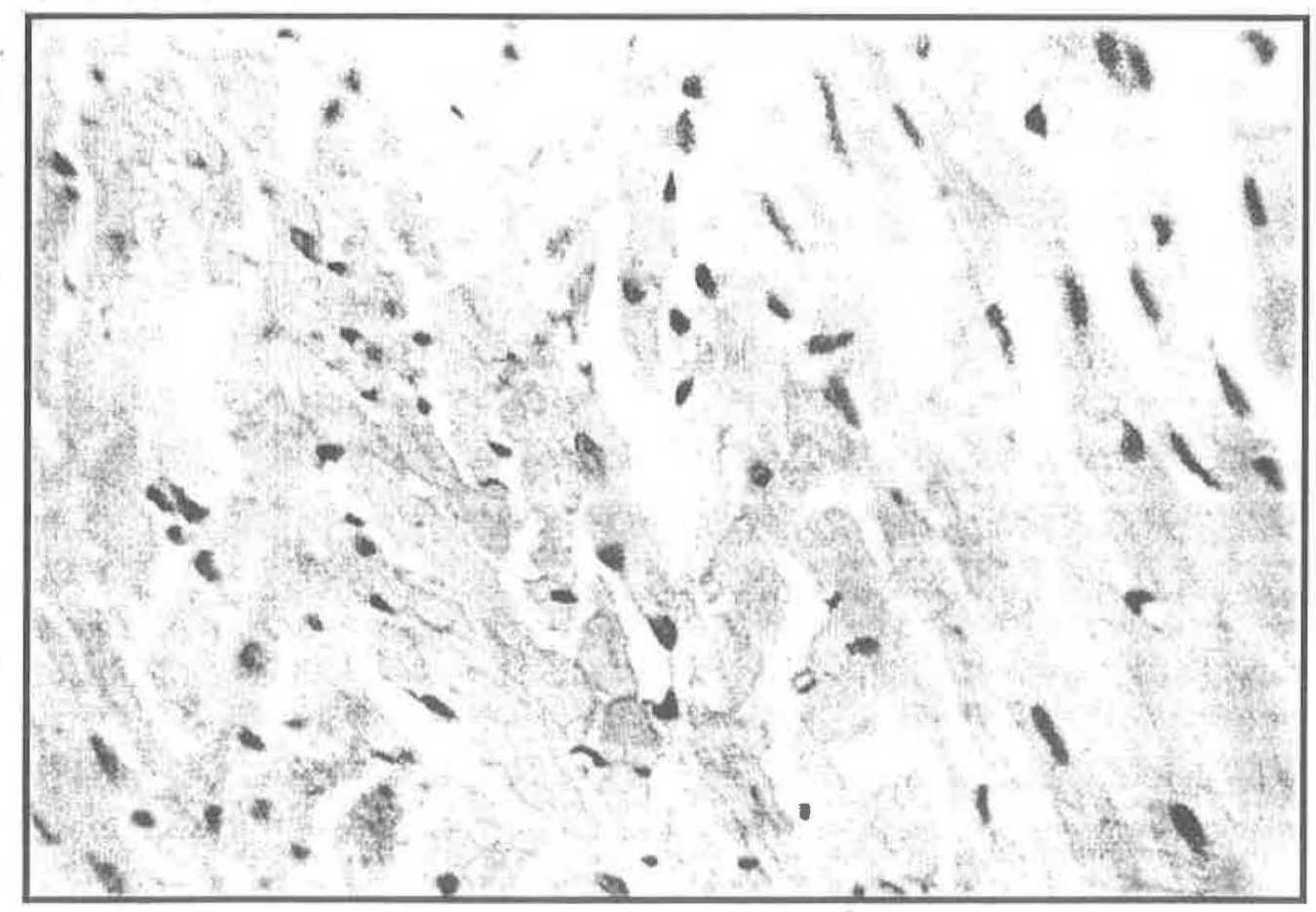

Fig.6: Histomicrograph of female rate heart sections treated with $0.5 \% \mathrm{H}_{2} \mathrm{O}_{2}$ for 60 days them treated with green tea for 40 days, revealed edema between muscle bundles of fibers, infiltration of mononuclear inflammatory cells and fatty degeneration. H \& E. 400x. 


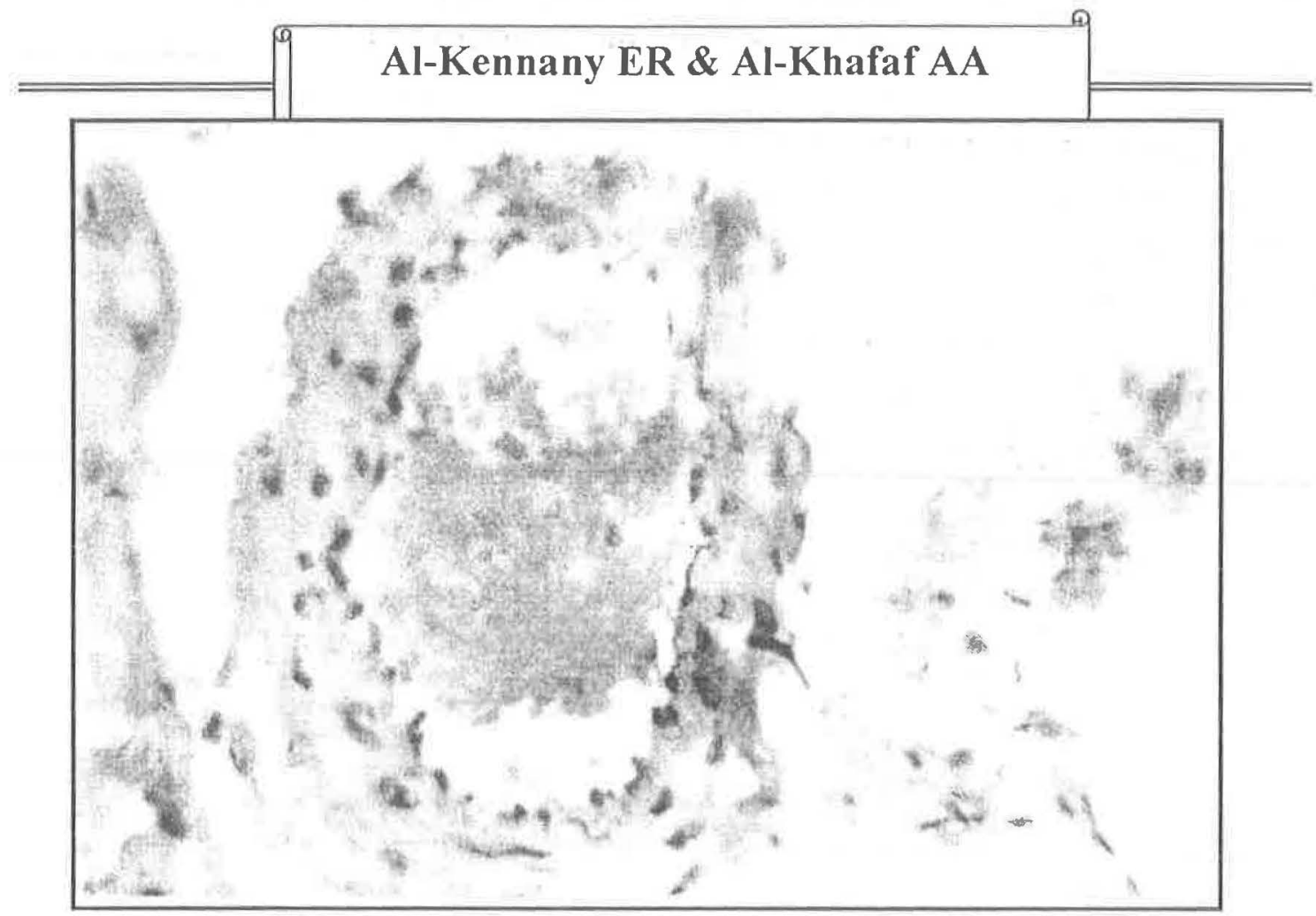

Fig.7: Histomicrograph of female rate heart sections treated with $0.5 \% \mathrm{H}_{2} \mathrm{O}_{2}$ for 60 days then treated with green tea for 40 days, revealed sever congestion in coronary artery and hypertrophy of endothelial cells. H \& E. 400x.

\section{Discussion}

This study demonstrate a marked elevation in level of plasma lipid profile. Lipid concentration of aorta and heart tissues of female rats dosed with $0.5 \% \mathrm{H}_{2} \mathrm{O}_{2}$ for 60 days, suggesting that these changes reflect susceptibility of these organs to experimentally induced atherosclerosis by oxidative stress that closely reseamble those found in human, chicken, rat, rabbit $(7,8)$. The source of these lipid peroxide was proposed to be the end product of lipoprotein metabolism (12).

Results of the present study revealed that a demonstration of $\mathrm{H}_{2} \mathrm{O}_{2}$ induces atherosclerosis in aorta on light microscope is similar with that report previously in aortas of chicken, rabbit, rat $(7,13)$. It is reasonable to consider the possibility that endothelial injury may be important in pathogenesis of those $\mathrm{H}_{2} \mathrm{O}_{2}$ induced lesions. Endothelial injury have been implicated in several experimental models of atherosclerosis that result from mechanical (14), chemical (15) infections or immunological injury (16).

This study used to test effects of green tea on antioxidant against $\mathrm{H}_{2} \mathrm{O}_{2}$ - induced oxidative stress in chicken and laboratory animals $(7,8)$. The importance of green tea as antioxidant due to it's content like epigallcatechin gallate (EGCG) the main antioxidant established atherosclerotic lesions Green tea provided in drinking water excreted a significantly ameliorating effects on lipid peroxidation and antioxidant status cause decrease in level of Tch, TGs, LDL-c, vLDL-c and 
atherogenic index (Table 1) as well as decrease concentration of MDA aorta and heart tissues associated with increase level of HDI,-c in serum and GSH of aorta and heart tissues. Our study suggested that EGCG one important contents in green tea and play important role in prevention endothelial cell-mediated LDLc lipid peroxidation and thereby inhibit expression of haem oxygenase and gene (17). However, green tea reduced the tendency of LDLc oxidize, and enhance cellular antioxidant enzyme activity or antioxidant defense (18).

However no protective effect of this dose of green tea was noted at the histopathological levels. Thus, the protective effects of green tea against $\mathrm{H}_{2} \mathrm{O}_{2}$ induced atherosclerosis may be due to changes in the antioxidant enzymes chain breaking antioxidant activity and have antiproliferative properties and it's ability to inhibit redox-sensitive signal transduction pathway related to cell growth on VSMcs (19). Green tea tended to less reduction the development of aortic atherosclerosis in female rats.

Our study found that oral administration of $0.5 \% \mathrm{H}_{2} \mathrm{O}_{2}$ to 60 days female rat induce lipid perxoidation concomitant with aortic lesions. Green tea treatment as antioxidant effective inhibited the $\mathrm{H}_{2} \mathrm{O}_{2}$-induced changes except the histopathological one therefore, the use of Green tea as antiatherogenic effect in female rats illustrated less histpathological effect on aortic lesions via less reduction in lipid vacuoles and induce proliferation of VSMcs in media toward the intimal layers.

\section{References}

1- Ahmad N. and Mukhtar H., Nut. Rev., 57: 78-83 (1999).

2- Mukhtar H. and Ahmad N., An. Soc. Clin. Nut., 71 (6): 1698-1702s (2000).

3- Luo M.K.K., Wahlqvist, Lancet, 349: 360-361 (1997).

4- Mahely RW., Arch Pathol Lab Med. 107: 393-9 (1983).

5- Tijburg LB., Wiseman SA., Meijer GW., Athero., 135: 37-47 (1997).

6- Muira Y., Chiloa T., Tomita I., J Nutr. 131: 27-32 (2001).

7- Al-Kennany E.R., Ph.D. Thesis. Vet. College of Vet. Med., University of Mosul (1998). (In Arabic).

8- Sayer J. and Timmis A., Circulation. 94: 1-8 (1996).

9- Gilbert Stump D.D. and Roth E.F.Jr, Anal. Biochem. 137: 282-286. (1989).

10- Moron, M.S., Depierre J.W. and Mennerivk B., Biochem. Biophys. Acta, 582: 67-78 (1979).

11- Drury R.A.B. and Willington E.A. "Carleetons' Histological Technique", $5^{\text {th }}$ Ed. Oxford University Press. (1980).

12- Wiztum JL and Steinberg D. J. Clin. Invest, 88: 1785-1892. (1991). 


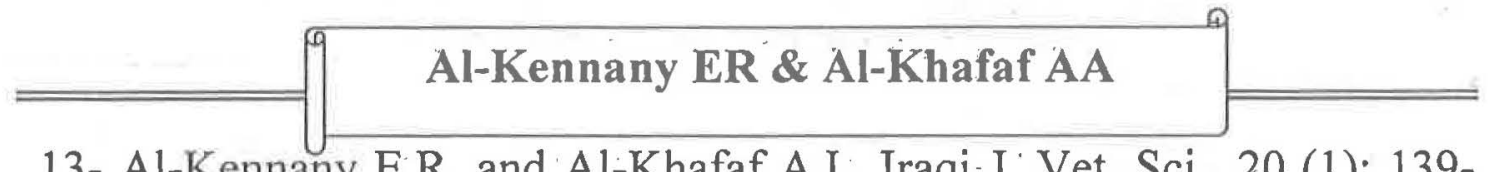

13- Al-Kennany E.R. and Al-Khafaf A.I., Iraqi - J. Vet. Sci., 20 (1): 139151 (2006).

14- Minik C.R., Fabricant C.G., Fabricant J. and Litrenta M.M., Pathol. 96: 673-706 (1979).

15- Ross R. and Harker L.A., Science, 193: 1094-1100 (1976).

16- Sharm H.M. and Geer J.C., Am. J. Pathol., 88: 255-266 (1977).

17- Soriani M., Rice-Evans C. and Tyrrell R.M., FEBS Letters, 439: 253257 (1998).

18- van het Hof K.H., De Boer H.S.M. and Wiseman S.A., Lien N., Weststral J.A. and Tijburg L.B.M., Am. J. CLin. Nutr. 66: 1125-1132 (1997).

19- van Het Holf K.H., Kivits G.A.A., Westestrate J.A. and Tijburg L.B.M. Eur. J. Clin. Nutr. 52: 365-9. (1998). 